\title{
EFFECT OF FAMILY ENVIRONMENT ON INTEREST IN ENTREPRENEURSHIP STUDENTS SMK IN SUBANG REGENCY
}

\author{
${ }^{1}$ Anita Wiani, ${ }^{2}$ Eeng Ahman, ${ }^{3}$ Amir Machmud \\ 1, 2, 3, Indonesian Education University \\ Email: anitawiani@gmail.com
}

\begin{abstract}
The emergence of a new business organization is caused by the human resources factor and the decision to entrepreneurship is determined by the environmental factors that influence a person to become an entrepreneur. Interest of entrepreneurs to entrepreneurship is still low so still need further research in order to increase the interest of learners especially in Vocational School (SMK) to become entrepreneur. It is necessary to increase the number of entrepreneurs as one determinant of the development of an area and the State. Entrepreneur is someone who has the advantage in running a business. The purpose of this study is to determine the relationship between the family environment with interest in entrepreneurship vocational school students in Subang Regency. The method used in this study is a survey where the techniques of collecting and analyzing data in the form of opinions from the subjects studied through questionnaires, interviews, and observation. In this study gives an idea that the family environment gives a significant influence on entrepreneurship interests of vocational school students in Subang Regency with a score obtained $0.000-0.043$. This research has a high degree of reliability that is equal to 0.703 .
\end{abstract}

Keywords: Entrepreneurship, Students Entrepreneurship, Family Environment, Interest Student be Entrepreneur

\begin{abstract}
ABSTRAK
Kemunculan sebuah organisasi usaha baru disebabkan oleh faktor sumber daya manusia dan keputusan untuk berwirausaha ditentukan oleh faktor lingkungan yang mempengaruhi seseorang untuk menjadi wirausaha. Minat peserta didik untuk berwirausaha masih rendah sehingga masih perlu penelitian yang lebih lanjut guna meningkatkan minat peserta didik khususnya di Sekolah Menengah Kejuruan (SMK) untuk dapat menjadi wirausaha. Hal tesebut diperlukan guna untuk meningkatkan jumlah wirausaha sebagai salah satu penentu perkembangan suatu daerah maupun Negara. Seorang wirasuaha merupakan seseorang yang yang memiliki keunggulan dalam sebuah bisnis/ usaha. Adapun tujuan dari penelitian ini yaitu untuk mengetahui hubungan antara lingkungan keluarga dengan minat berwirausaha peserta didik SMK di Kabupaten Subang. Metode yang digunakan dalam penelitian ini yaitu survey dimana teknik pengolahan dan analisis data dalam penelitian ini menggunakan angket, wawancara, dan observasi langsung. Lingkungan keluarga dalam penelitian ini memiliki pengaruh yang signifikan terhadap minat berwirausaha peserta didik SMK di Kabupaten Subang dengan skor 0.000-0.043. Penelitian ini memiliki reliabilitas yag tinggi dengan skor mencapai 0.703.
\end{abstract}

Kata Kunci: Kewirausahaan, Kewirausahaan Siswa, Lingkungan Keluarga, Minat Siswa menjadi Pengusaha 


\section{PRELIMINARY}

Based on Global Enterpreneur Index (GEI) data in 2015, developed countries from both the economic and industrial sectors are shown by the growth index of entrepreneurship, whereas according to data from GEI Indonesia occupies 120th position of 130 with the score of 21.0 being the 10th lowest, to be able to have entrepreneurial spirit and give birth to new business baru (Mandiri, Dan, Lestari, Hasiolan, \& Minarsih, 2016). The number of graduates from various fields of science from year to year increase, on the one hand this condition is not balanced with the amount of employment in both industry and government, causing high number of unemployment (Kusumawati, 2016). The Indonesian entrepreneurship sequence based on data obtained from Global Entrepreneurship Monitor (GEM) 2015-1016 Year Indonesia is still low when compared with other countries especially among other ASIA members.

Table 1

Order of Entrepreneurship by Region and

Percentage of Population by Age 18-64 Years

\begin{tabular}{|c|c|c|c|c|c|c|c|}
\hline \multirow{2}{*}{$\begin{array}{l}\text { Re- } \\
\text { gion }\end{array}$} & \multirow[t]{2}{*}{ Economy } & \multicolumn{2}{|c|}{$\begin{array}{l}\text { Entrepreneurship as a } \\
\text { Good Career Choice }\end{array}$} & \multicolumn{2}{|c|}{$\begin{array}{c}\text { High Status to } \\
\text { Successful Enrepreneurs }\end{array}$} & \multicolumn{2}{|c|}{$\begin{array}{l}\text { Media Attention for } \\
\text { Entrepreneurship }\end{array}$} \\
\hline & & Rank/54 & Value & Rank/54 & Value & Rank/54 & Value \\
\hline \multirow{14}{*}{$\begin{array}{c}\text { Asia } \\
\& \\
\text { Ocea } \\
\text { na }\end{array}$} & Australia & 36 & 56.4 & 21 & 70.1 & 10 & 72.3 \\
\hline & China & 22 & 65.9 & 13 & 77.6 & 6 & 77.2 \\
\hline & India & $50 \mathrm{~T}$ & 39.3 & 53 & 46.6 & 52 & 39.4 \\
\hline & Indonesia & 6 & 74.4 & 7 & 81.4 & 4 & 79.4 \\
\hline & Iran & 37 & 56.3 & 5 & 82.3 & 35 & 58.3 \\
\hline & Israel & 23 & 64.5 & 1 & 86.2 & 37 & 54.8 \\
\hline & Kazakhstan & 4 & 76.9 & 3 & 83.9 & 3 & 80.0 \\
\hline & Korea & 52 & 38.0 & 47 & 53.5 & 26 & 61.5 \\
\hline & Malaysia & $50 \mathrm{~T}$ & 39.3 & 50 & 51.0 & 24 & 63.9 \\
\hline & Philipines & 5 & 74.6 & 14 & 76.2 & 2 & 81.5 \\
\hline & Taiwan & 7 & 74.0 & 39 & 62.7 & 1 & 85.6 \\
\hline & Thailand & 15 & 71.5 & 27 & 69.4 & 9 & 72.5 \\
\hline & Vietnam & 11 & 73.3 & 16 & 75.8 & 8 & 73.5 \\
\hline & Total & & 61.9 & & 70.5 & & 69.2 \\
\hline
\end{tabular}

Source: Global Entrepreneurship Monitor (GEM) Year 2015-1016

Based on the table we can see that the selection of career as an entrepreneur from the Indonesian population aged 18 to 64 years is still low that is as much as 7 percent, while Malaysia is much larger that reaches 50 percent. In a previous study conducted by Resti Elfia Shanti referring to the Central Bureau of Statistics data on Indonesian population data aged 15 years and over by the main employment status of August 2013 - August 2015 stated that as many as 18.15 percent work as self-employment, the figure is much more slightly compared with the number of workers / employees as much as 46.24 percent.

Table 2

Job Seeker Data Based on Education Level 2017

\begin{tabular}{ccccccc}
\hline Level & Januari & Februari & Maret & April & Mei & Juni \\
\hline $\begin{array}{c}\text { Vocational high school } \\
\text { (SMK) }\end{array}$ & $41.21 \%$ & $27.70 \%$ & $33.97 \%$ & $62.67 \%$ & $60.14 \%$ & $50.57 \%$ \\
Senior high school (SMA) & $37.17 \%$ & $56.75 \%$ & $37.97 \%$ & $17.52 \%$ & $30.36 \%$ & $39.96 \%$ \\
Others & $21.62 \%$ & $15.55 \%$ & $28.06 \%$ & $19.81 \%$ & $9.50 \%$ & $9.47 \%$ \\
\hline Source: Department of Manpower and Transmigration Subang Regency (Data processed)
\end{tabular}

Based on the data in the above table it can be seen that job seekers in Subang Regency mostly derived from SMK graduates. So many job seekers SMK graduates can not be fully absorbed by the World Business/ Industrial World (DU / DI). 
Researchers conducted a pre-research at SMK PGRI Subang with a sample of 329 learners from 7 competency expertise, namely: majoring in Marketing, Office Administration, Accounting, Clothing Boutique, Technical Business Motorcycle, Computer Network Engineering, Hotel Accommodation, where the results of the survey showed still lack of entrepreneurship interest in the students in SMK PGRI Subang. If the condition continues, it can have a bad impact on the economy in Subang Regency, besides the vision of SMK PGRI Subang also difficult to achieve, namely to become a leading school of entrepreneurship in accordance with the competence of religious skill and environmentally sound.

Some developing countries where low development in the country is associated with the problem of new ventures, where the birth of new business becomes a serious problem for the country (Leef, 2015). On the other hand, the interest of entrepreneurship in Indonesia is still very low where the number of entrepreneurs in Indonesia is only 0.18 percent of the population, still far below other countries that is compared to Malaysia which is 2 percent, America 4 percent and Singapore 7 percent. A country will progress and stabilize its economy if the population who become entrepreneurs at least 2 percent of the total population of citizen (Aprilianty, 2012). Ernanie in her workshop revealed there is a tendency, the higher the level of education the greater the desire to get a safe job so they do not dare to take a risky job such as entrepreneurship (Asawi, 2011). Economic development of a region or a country is basically an interaction of various groups of variables such as human resources, natural resources, capital, technology and others (Kemiskinan, Ekonomi, Belanja, Tahun, \& Mirza, 2012). Entrepreneurship affects the development of a country (Burger-Helmchen, 2012). One solution offered by the government to reduce the unemployment rate is to create employment with entrepreneur model (Yusanto: 2002 in dalam (Asawi, 2011). Entrepreneurship in Indonesia should be improved, with entrepreneurship will create new jobs and will absorb labor, reducing unemployment (Chinmay et al., 2016). Vocational High School (SMK) has a large enough opportunity to participate in developing the economic system by utilizing the stage of adolescent development, educating students to be interested in becoming entrepreneurs (Aprilianty, 2012).

The emergence of a new business organization is caused by human resource factors (Lichtenstein, Carter, Dooley, \& Gartner, 2007). The decision to enter into entrepreneurship is determined by environmental factors affecting an entrepreneur (Fu, 2016). In recent years many economists have argued that the entrepreneurial spirit is closely related to the size of the company itself (Gicheva \& Link, 2015), while the new technology used by new entrepreneurs is an effort not only to expand business but also to make ends meet. (Gicheva \& Link, 2015). According to Alam (2010: 12) the most encouraging one to enter the entrepreneurial career that is personal attribute and personal environment (Aprilianty, 2012). Entrepreneurship is a way of thinking, studying, and acting based on a balanced business opportunity, holistic approach, and leadership (Timmons \& Spinelli, n.d.). Entrepreneurship is a creative and innovative ability that is used as the basis, tips, and resources to find opportunities for success (Asawi, 2011). Previous research has concluded that family environments have an effect on entrepreneurial interests where interest can be defined as something that arouses attention to something and interests indicates what people want or do or what they enjoy (Aprilianty, 2012).

The role of the family is also very important in fostering interest in entrepreneurship (Wisnu Septian Ginanjar Prihantoro dan Hadi, 2016). Entrepreneurship education can take place from an early age in a family environment where a mother and an entrepreneurial father inspire children to become entrepreneurs (Aprilianty, 2012). In this research, the theoretical framework describes the influence of the family environment factor of the students on the entrepreneur interest. The problems faced by developing countries, especially the low level of entrepreneurship as happened in Indonesia cause researchers interested to lift it in research. 


\section{THEORITICAL REVIEW}

\section{Entrepreneurship}

The word of entrepreneur is broadly emerged after the issuance of Presidential Instruction (Inpres) RI Number 4 Year 1995 dated June 30, 1995 about the national movement to socialize and cultivate entrepreneurship, and istila is equivalent to the term entrepreneur. Entrepreneurs taken from the French language means beteen taker or gobetween, if translated into English becomes to undertake (Astamoen, 2008).

According to the Encyclopedia of America (1984), entrepreneurs are entrepreneurs who have the courage to take risks by creating production, including capital, labor and materials, and from business profits. According to The American Heritage Dictionary of the English Language, entrepreneurs are defined as "a person who organizes, operates, and assumes the risk for a business venture," in other words that entrepreneurs are people who manage and operate a business and are able to manage risk (Astamoen, 2008).

Attachment of Decree of Minister of Cooperative and Small Entrepreneur Development Number 961/KEP/M/XI/1995, stated that Entrepreneur is a person having enthusiasm, attitude, behavior and entrepreneurship, while according to Suryana (in Asawi, 2011) an entrepreneur can be described; have commercial insight and market awareness, have the will to work diligently and independently, have innovative and creative minds, have the ability to manage and direct the association, have the ability to mix with others of all actions. Entrepreneurship comes from the word wira and effort, wira contains superior human meaning while the business means to do something so that entrepreneur is someone who has the advantage in running a business in this case contains the understanding of something that is business. An entrepreneur is someone who develops new products or new ideas and builds a business with a new concept, in that it demands some creativity and an ability to see the prevailing trends to become an entrepreneur (Aprilianty, 2012). According to Victor Kiam entrepreneur is a person who easily finds little difference between obstacles and opportunities and able to take advantage of the that's condition (MacMillan, 2010). Meredith said that entrepreneurs are people who have the ability to see and assess business opportunities and collect the resources needed to take advantage of it and take appropriate action to make sure be success, whereas according to Totok S. Wiryasaputra an entrepreneur is a person who wants to be free, independent, regulating his own life, and not dependent on the mercy of others. This opinion is in line with Kao's deficits of deficiency, in which Kao defines entrepreneurship by emphasizing the aspect of freedom of expression stated as follows: "An entrepreneur is and independent, growth-oriented owner-operator", thus an entrepreneur is a person who has the ability to see and assessing business opportunities, gathering the resources needed to take advantage of it and taking appropriate action to ensure success (Yuyus Suryana \& Kartib Bayu, 2010).

Teory of Planned Behavior (TPB) explains that one's intentions toward behavior are shaped by factors; attitude toward behavior, subjective norms, and perceived behavioral control. Appropriate TPB is used to describe a variety of behaviors within entrepreneurship. As stated by Ajzen (1991) that TPB is suitable to explain any behavior which requires planning, such as entrepreneurship (Budi Wahyono, Siswandari, 2013).

The relationship of these three dimensions (Ajzen, 2005) Ajzen explains that; (1) attitudes toward behavior are determined by beliefs about the consequences of a behavior, beliefs related to the individual's subjective judgment of the world around him as well as the individual's understanding of himself and his surroundings is done by linking certain behaviors with the various benefits and disadvantages to be gained if doing or not do it. (2) the subjective norm is the individual's perception of the expectations of influential people in his or her life about whether or not to do so. The subjective norm is also influenced by belief. (3) Behavioral control is an individual's perception of the easy or difficulty of manifesting certain behaviors, while behavioral control is closely related to the self-efficacy concept proposed by Bandura where self efficacy is the individual's belief that he or she will successfully master the skills required to accomplish a particular task (Ramdhani, 2011). 
Entrepreneurship is a way of thinking, studying, and acting based on business opportunities, a holistic approach and a balanced leadership whereby entrepreneurship generates creation, progress, realization and renewal of company value not only for the owner but also for employees and shareholders (Timmons \& Spinelli, n.d.). According to Miller Entrepreneurship represents organizational behavior in which the main elements of entrepreneurship are risk-taking, proactive and innovative (Thomson, 2006). According to Usman, entrepreneurial understanding in the context of management is someone who has the ability to use resources, such as finance, raw materials and labor to produce a new product, new business, production process or organization development where the entrepreneur is someone who has a combination of elements internal that includes a combination of motivation, vision, communication, optimism, encouragement and ability to take advantage of business opportunities so that it can be concluded that the entrepreneur is a pioneer in business, innovators, risk takers, who have a vision for the future and have excellence in achieving in business (Hakim, 2010).

In the attachment to the Ministerial Decree of the Minister of Cooperatives and Small Scale Business Development Number 961 / KEP / M / XI / 1995, it is stipulated that Entrepreneurship is the spirit, attitude, behavior and ability of a person in handling business or activity that leads to searching, creating and applying work, and new products by increasing efficiency in order to provide better service and or gain greater benefits. Entrepreneurship is an ability to create value-added in the market through the process of managing resources in different new ways, through; development of new technologies, the discovery of new scientific knowledge, improvements to existing products and services, the discovery of new ways to produce more goods with more efficient resources. (Asawi, 2011).

In the 1950s, entrepreneurship education began in several countries such as Europe, America and Canada, since the 1970s many universities or universities have taught entrepreneurship "entrepreneurship" or "small business management" or "new venture management" in the 1980s nearly 500 schools in the United States provided Entrepreneurship education, which at that time in Indonesia entrepreneurship was studied only limited to certain schools or colleges only (Hakim, 2010). Entrepreneurship education has been taught as an independent independent discipline, which according to Soeharto Prawirokusumo is due to:

1. Entrepreneurship contains a "body of knowledge" that is full and distinctive, ie there is a complete theory, concept, and scientific method.

2. Entrepreneurship has two concepts, namely the position of "start-up venture" and "venture growth". This is obviously not included in the "frame work general management courses" that separate "management" from "business ownership"

3. Entrepreneurship is a discipline that has its own object, namely the ability to create something new and different. Entrepreneurship is a tool to create equitable distribution of wealth and prosperity of the people.

The process of entrepreneurship is the creation or discovery of business opportunities followed by the will and action of seizing opportunities. Classical entrepreneurship according to Timmons and Spinelli in his book entitled New venture creation entrepreneurship for the 21st century is a beginner company that is still raw starting with the idea of a business that later developed into a large company. A successful entrepreneur has a strong leadership and is able to work together in a team and be able to grasp the opportunities for bisexual-contradictory and confused, besides entrepreneurship requires the skills of searching and controlling resources.

According to (Suryana, 2006) in his book Innovation and Entrepreneurship Drucker proposes the development of entrepreneurship theory into three stages: a) The theory that prioritizes business opportunities, this theory is called economic theory, ie entrepreneurship will emerge and develop if there is economic opportunity; b) Theories that prioritize people's response to opportunities, namely Sociological theories that try to explain why some social groups show different responses to business opportunities and psychological theories that try to answer the characteristics of individuals that distinguish entrepreneurship and not 
entrepreneurship and individual characteristics that distinguish entrepreneurship is successful and not successful and c) The theory that prioritizes the relationship between entrepreneurial behavior with the results, called behavioral theory, which is trying to understand the pattern of entrepreneurial behavior wirausaha (Wibowo, 2011). Below is a framework of thinking about entrepreneurship according to Yuyus Suryana and Katib Bayu (Yuyus Suryana \& Kartib Bayu, 2010).

Hisrich \& Peter (2002: 52) mentions that the characteristics of entrepreneurship there are 7 namely; an entrepreneur has the ability to understand the environment, has a vision or outlook and flexible / not rigid, has the creativity in business management, can work together in teams, open, can build cooperation in advancing the company, and able to defend themselves (Sukardi, 2013). The characteristics of entrepreneur by Timmons and Spinelli namely; (Timmons \& Spinelli, n.d.), whereas according to Thomson that entrepreneurial success lies in the involvement of entrepreneurial roles in managerial firms that are compatible with the culture and organizational structures that support (Thomson, 2006). Describing entrepreneurial behavior is closely related to the commitment that entrepreneurs own in running their business (Bill, Bjerke, \& Johansson, 2010)

Bygrave (Yuyus Suryana \& Kartib Bayu, 2010) suggests some characteristics of a successful entrepreneur having the following haracteristics:

1. Dream, an entrepreneur has a vision of how he wants his personal and business future including the ability to realize his dream.

2. Decisiveness, an entrepreneur is a person who does not work slowly, make quick decisions with full calculation and this is the key to the success of his business.

3. Doers, once the perpetrator takes immediate actionable action, and does not want to delay the opportunities that can be exploited.

4. Determination, that in carrying out activities carefully, the sense of responsibility is high, and not easily give up even though faced with obstacles that are difficult to overcome.

5. Dedication, dedication is very high, and sometimes more concerned with business than his family.

6. Devotion, very happy and infatuated and loves his business including the resulting product so that it becomes a driving force in achieving effective success in selling and offering its products.

7. Details, careful attention to critical factors in detail and not ignore the small things that can hamper his business.

8. Destiny, he is responsible for the goal to be achieved, and not dependent on others and have freedom.

9. Dollars, his motivation instead of earning money and money is considered a measure of success after his business succeeds.

10. Distribute, an entrepreneur willing to distribute business ownership of people who can be trusted, critical, and willing to be invited to achieve success in his business.

Pearce in Winardi (2003: 37) suggests the characteristics of successful entrepreneurs

(Yuyus Suryana \& Kartib Bayu, 2010), as follows:

1. Unlimited commient and determination

2. Strong encouragement or stimulus to achieve achievement

3. Orientation towards opportunities and goals

4. Confident in yourself

5. Tolerance to ambiguity

6. Prepare to anticipate problems that may arise

7. Stay focused on opportunities, customers, markets, and competition

8. Not intimidated by difficult situations

9. Aggressively seek feedback that enables speeding up progress and effectiveness

10. Ability to face failure effectively and can accept failure and use it as a learning process Meanwhile, according to Ari Wibowo Prijosaksono (2003) (Yuyus Suryana \& Kartib

Bayu, 2010) there are ten things that must be owned by an entrepreneur, namely:

1. Find your purpose and dream all the time, ie a successful trip is not a destination 
2. Never-ending innovation, ie endless innovation Learn-change and grow, always learn, learn, and learn

3. Accumulative your asset - end goal of the entrepreneur is achieving financial freedom

4. Use leverage concept to build your business, a savvy entrepreneur must be able to use the power and time of others to achieve the goal

5. Nurture equip develop your people, able to use other time and energy to reach the destination

6. Systemize your business, able to build an effective and efficient business system

7. Buikd network and alliance, able to create a strong network both in terms of business opportunities, capital, and access to government

8. Be smart investors, one of the smart entrepreneurial power and success is the ability to manage its asset portfolio so that it continues to grow and multiply

9. The power of giving: give and be grateful, the true entrepreneur's habits are charity and give thanks.

\section{Family Environment}

The family is the smallest unit of society that consists of the head of the family and several people who are gathered and live somewhere under a roof in a state of interdependence. According to Salvicion and Celis (1998) in the family, there are two or more persons belonging to blood, marriage or rapture, in their life in one household, interacting with each other and in their respective roles and creating and maintaining a culture. Joe Kathena argues that the environment is everything that is outside the individual that includes the physical and socio-cultural, this environment is the source of all information received by the individual through the means of senses of sight, smell, hearing, and taste (Syamsu Yusuf, 2000).

Family environment is very influential in the development of a child's personality because the family environment is the primary environment that strongly influences the individual compared to the secondary environment (community). Understanding the environment of the family comes from the word environment and family, according to (Webster's New College Dictionary in Hadikusumo, 1996: 74) understanding of the environment is a collection of all conditions and external influences on the life and development of an organization (Hadikusumo, Kunaryo, 1996).

The family is the father's mother with their children; a whole house of dependents (Poerwadarminta, 1989). In the broadest sense the family is a living alliance that is woven of affection between the couple of two types of human beings affirmed by marriage, who intend to perfect one another (Soelaeman, 1994). The family is the first social group in the human life in which he learns and manifests himself as a social human in the interaction with his group. In his family, whose family's social interactions are based on sympathy, a child first learns to pay attention to the wishes of others, learns to cooperate, helps, in other words, the child first learns to play a role as a social being with norms and a certain skillful prowess in association with others. Parents' work is often seen that there are influences from parents who work alone and open their own business then tend to be his son will become entrepreneurs (Alma, 2009). The state where the business itself, then this is used as inspiration by the child. Such parents tend to support the courage of their children to start their own business as adults. Parents or families are also the founders of preparing children for the future to become effective workers (Soemanto, 2008).

In educating children, parents should teach their children to motivate themselves to work hard, given the opportunity to take responsibility for what he does. Parents who have entrepreneurship in a particular field may generate their child's interest in entrepreneurship in the same field. Having an entrepreneurial mother and father inspires her child to become an entrepreneur. The flexibility and independence of entrepreneurship has been ingrained in children from an early age. The child is inspired to entrepreneurship because of seeing the seriousness and hard work of his father and mother or parents trying to make a profit. So to cultivate interest in entrepreneurship within the child. From the understanding of the 
environment and family above, it can be concluded the definition of family environment is all conditions and influence from outside to the life and development of family members.

Family environment is one of the environmental factors that can affect a person's interest to entrepreneurship. Factors contained in the family environment consists of: a) The way parents educate. The way parents educate their children great influence on how to learn and think child. There are parents who educate military dictators, some are democratic and there are also families who are indifferent to the opinions of every family. b) Relation between family members. The most important relation among family members is the relationship of parents with their children. For the sake of smooth learning and success of children, need a good relationship within the family. A good relationship is a relationship of understanding and compassion, accompanied by guidance to succeed in children's learning. c) The atmosphere of the house. The atmosphere of the home is meant as a situation or events that often occur in families where children are and learn. The home atmosphere is an important factor that does not include intentional factors. The atmosphere of the house is noisy / crowded and chaotic will not give peace to children who learn. The tense, noisy, and often tense atmosphere of the house among family members or with his family. d) Family economic conditions in families with relatively low economic conditions, parents are unable to meet the basic needs of children. Not infrequently the economic difficulties factor would be a motivator or a driver of children to be more successful. As for the excessive economic families, parents tend to be able to meet all the needs of children including children's education problems including being able to continue up to a high level. Sometimes all-sufficient condition makes the parents less attention to the child because it feels fulfilling all the needs of his child, consequently the child becomes lazy to learn and achievement will not be good. e) Understanding Parents. Child learning needs encouragement and understanding from parents. Sometimes children experience weak spirit, then parents must give understanding and encourage, help as much as possible difficulties experienced by children both at school and in the community. It is important to keep his confidence growing. f) Cultural Background. Education levels or habits within the family affect the attitude of the child in his life (Slameto, 2010).

\section{LITERATURE RIVIEW}

The pervasive effects of family on entrepreneurship: toward a family embeddedness perspective

Howard E. Aldrich, Jennifer E. Cliff (2003) Family and business often occur as naturally differentiating institutions, while we argue because they are closely intertwined. Long-term changes in family composition and role. Family relationships in North America grow smaller and lose many relationships. Such transformations in the sense of implications for business, new opportunities, new business start-up decisions, and support for resource mobilization. We allow entrepreneurial experts to start new ventures and resource mobilization processes. We allow entrepreneurial experts to benefit from the perspective of family engagement on the acceleration of new ventures (Aldrich \& Cliff, 2003)

We need more research on ways of influencing, and the process of new resources, and the process of resource mobilization. We need to learn more about the things used by the features, how and how best to know what is needed and decide to run the business needed to understand the existing system. Such research will be able to research the socialization of entrepreneurship and also pave the way for a more holistic and more realistic way to discuss entrepreneurial phenomena, especially in new business sectors.

\section{The Family's Financial Support as a "Poisoned Gift": A Family Embeddedness Perspective on Entrepreneurial Intention}

Philipp Sieger, Tommaso Minola (2016) We argue that the availability of greater family financial support to create new ventures requires stronger financial and non-financial obligations. Recognizing this obligation, the potential of the founders anticipates the 
negative performance implications for the planned company and the threat of the family system in case of non-fulfillment of their needs. Thus we postulate that the actual formation of intentions for entrepreneurship tends to be large with the availability of available financial support. This study studied the sample of 23,304 respondents from 19 countries and found a negative relationship on family cohesion and on the individual self-confidence to entrepreneurship (Sieger Philipp, 2016)

\section{Analysis of the influence of external and internal factors on entrepreneur interest}

Komsi Koranti 2013Increased population and limited employment create unemployment problems in Indonesia. Various efforts have been made by the Government, among others, with the community's self-supporting business in the field of entrepreneurship. There are various factors that affect entrepreneurial interests, namely internal and external. Multiple linear regression analysis is used to understand the extent to which the influence of these factors on entrepreneurship interest. This research method is surbey eksplanatory, object of this research is student of Gunadarma University in Depok. The number of samples of 100 students taken with a simple random sample technique using a questionnaire. The results of this study concluded that the most influential variables on entrepreneurship interest are motivation, personality, family environment and the environment (Koranti, 2013)

\section{The influence of attitude, education and family environment on entrepreneurship interest}

Ni putu pebi ardiyani, a.a.g agung artha Kusuma Interests are a sense of interest in objects or activities that come from self-ability. Interest encourages individuals to engage in activities in a defined purpose. This research was conducted at Faculty of Economics and Business Universitas Ganesha with the number of respondents as many as 100 students using Slovin method. Data collection conducted by using questionnaire. The analysis technique used is multiple regression. The result of analysis shows that attitude, education and family environment have positive and significant influence to entrepreneur interest (Putu, Ardiyani, \& Kusuma, 2016)

\section{RESULT}

Based on the analysis of the results of data processing research, it can be concluded that the influence of family environment has a significant influence on entrepreneurship interests of vocational school students in Subang Regency. The score obtained is 0,000 0.043 which according to Utari Sumarmo and Heris Hendriana (Sumarmo Utari, 2014) that the significance level of $5 \%$ or 0.05 is valid. Scores obtained in the reliability test in this study of 0.703 has a high degree of reliability, according to J.P. Guildford (Suherman, 2003).

\section{CONCLUSIONS AND RECOMMENDATIONS}

Building a new business has a positive impact on the development of a nation. Entrepreneur is someone who has the advantage in running a business / business. Interest in entrepreneurship among students especially Vocational High School (SMK) needs to be improved. There are several factors that influence the increase of entrepreneurship interest in vocational school students such as internal and external factors, but family environmental factors greatly affect the entrepreneurship interests of vocational school students in Subang Regency. If the learners are in a family environment that entrepreneurship can provide encouragement to the students themselves to be able to continue the family business and inspire the learners themselves to open their own business, and provide support to start and run a business.

This research can provide advice to other parties to always support in increasing the interest of learners for entrepreneurship, including policy stakeholders in schools, government, and Business / Industrial World. It is expected that further research can be 
done empirically to know the magnitude of family environment influence to entrepreneurship interest in learners especially learners in SMK.

\section{REFERENCES}

Ajzen, I. (2005). Attitudes, Personality, and Behaviour.

Aldrich, H. E., \& Cliff, J. E. (2003). The pervasive effects of family on entrepreneurship: toward a family embeddedness perspective, 18, 573-596. http://doi.org/10.1016/S0883-9026(03)00011-9

Alma, B. (2009). Kewirausahaan. Bandung: Alfabeta.

Aprilianty, E. (2012). Pengetahuan Kewirausahaan, Dan Lingkungan the Effect of Entrepreneur Personality, Entrepreneurship Knowledge , and Environment on Entrepreneurial Interest. Pendidikan Vokasi, 2(3), 311-324. http://doi.org/10.1007/s11365-012-0246-x

Asawi, N. (2011). Wirausaha Sebagai Solusi Pengangguran Terdidik Di Indonesia. Ejournal Uin Malang, 7(no 2), 1-21. Retrieved from http://ejournal.uinmalang.ac.id/index.php/ekonomi/article/view/1754

Astamoen, I. H. M. P. (2008). Entrepreneurship dalam Perspektif Kodisi Bangsa Indonesia. Bandung: Alfabeta.

Bill, F., Bjerke, B., \& Johansson, A. W. (2010). (De)mobilizing the entrepreneurship discourse: Exploring entrepreneurial thinking and action. (De)Mobilizing the Entrepreneurship Discourse: Exploring Entrepreneurial Thinking and Action. Retrieved from 80755160103\&partnerID=tZOtx3y1 http://www.scopus.com/inward/record.url?eid=2-s2.0-

Budi Wahyono, Siswandari, D. S. (2013). Pengaruh Pendidikan Kewirausahaan Terhadap Niat Berwirausaha Siswa SMK Negeri 1 Pedan Tahun 2013, 1-17.

Burger-Helmchen, T. (2012). Entrepreneurship- Born, Made and Educated, 350. http://doi.org/10.5772/35302

Chinmay, L., Mengze, P., Chinmay, L., Mengze, P., Decision, M., Intelligence, M., ... Decision, M. (2016). Article information: Journal of Small Business and Enterprise Development, 19(3), 25. http://doi.org/10.1108/02656710210415703

$\mathrm{Fu}, \mathrm{W}$. (2016). Industrial clusters as hothouses for nascent entrepreneurs? The case of Tianhe Software Park in Guangzhou, China. The Annals of Regional Science, 57(1), 253-270. http://doi.org/10.1007/s00168-016-0776-3

Gicheva, D., \& Link, A. N. (2015). On the Economic Performance of Nascent Entrepreneurs Department of Economics Working Paper Series. Department of Economics Working Paper Series, (July).

Hadikusumo, Kunaryo, D. (1996). Pengantar Pendidikan. Semarang. Semarang: IKIP Semarang Press.

Hakim, A. (2010). Model Pengembangan Kewirausahaan Sekolah Menengah Kejuruan ( Smk ) Dalam Menciptakan Kemandirian Sekolah, 4(1), 1-14.

Kemiskinan, P., Ekonomi, P., Belanja, D. A. N., Tahun, T., \& Mirza, D. S. (2012). Economics Development Analysis Journal, 1(1), 224-234.

Koranti, K. (2013). ANALISIS PENGARUH FAKTOR EKSTERNAL DAN INTERNAL, 5(1998), 8-9.

Kusumawati, D. (2016). ANALISA PENGARUH FAKTOR INTERNAL DAN MAHASISWA SISTEM INFORMASI STMIK AKAKOM, 11-13.

Leef, N. H. (2015). Entrepreneurship Economic Development: The Problem Revisited, 17(1), 46-64. 
Lichtenstein, B. B., Carter, N. M., Dooley, K. J., \& Gartner, W. B. (2007). Complexity dynamics of nascent entrepreneurship. Journal of Business Venturing, 22(2), 236261. http://doi.org/10.1016/j.jbusvent.2006.06.001

MacMillan, A. (2010). Be a great entrepreneur.

Mandiri, P. S., Dan, L. K., Lestari, A., Hasiolan, A. B., \& Minarsih, M. M. (2016). ( Studi Empiris di Desa Jamus Kecamatan Mranggen Kabupaten Demak ). PENGARUH SIKAP MANDIRI, LINGKUNGAN KELUARGA DAN MOTIVASI TERHADAP MINAT BERWIRAUSAHA PARA REMAJA, 2(2).

Poerwadarminta. (1989). Kamus Umum Bahasa Indonesia. Jakarta: Depdiknas.

Putu, N., Ardiyani, P., \& Kusuma, A. A. G. A. A. (2016). Pengaruh Sikap, Pendidikan dan Lingkungan Keluarga Terhadap Minat Berwirausaha, 5(8), 5155-5183.

Ramdhani, N. (2011). Penyusunan Alat Pengukur Berbasis Theory of Planned Behavior 1, 19(2), 55-69.

Sieger Philipp, M. T. (2016). The Family â€ $€^{\mathrm{TM}}$ s Financial Support as a "Poisoned Gift ": A Family Embeddedness Perspective on Entrepreneurial Intention The Family' $s$ Financial Support as a "Poisoned Gift ": A Family Embeddedness Perspective on Entrepreneurial Intentions, (September). http://doi.org/10.1111/jsbm.12273

Slameto. (2010). Belajar dan Faktor-Faktor yang Mempengaruhinya. Jakarta: Rineka Cipta.

Soelaeman. (1994). Pendidikan Dalam Keluarga. Bandung: Alfabeta.

Soemanto, W. (2008). Pendidikan Wirausaha. Jakarta: PT. Bumi Aksara.

Suherman, E. (2003). Penelitian Pembelajaran Matematika Kontemporer.pdf. Bandung: Universitas Pendidikan Indonesia.

Sukardi, T. (2013). Faktor-Faktor Yang Mempengaruhi Kemandirian Factors Influence the Autonomy for Entrepreneure in Student' S Smk. Jurnal Pendidikan Vokasi, 3(November), 334-346.

Suryana. (2006). Kewirausahaan Pedoman Praktis: Kiat dan Proses Menuju Sukses. Jakarta: Salemba Empat.

Syamsu Yusuf. (2000). Lingkungan keluarga.

Thomson, J. D. (2006). Entrepreneurship and Innovations in E-Business. Entrepreneurship and Innovations in E-Business: An Integrative Perspective. http://doi.org/10.4018/9781-59140-920-5

Timmons, J. A., \& Spinelli, S. (n.d.). Jeffry A. Timmons and Stephen Spinelli New Venture creation Entrepreneurship for the 21, 21.

Wibowo, A. (2011). Pendidikan Kewirausahaan. Jakarta: Pustaka Pelajar.

Wisnu Septian Ginanjar Prihantoro and Hadi, S. (2016). KELUARGA TERHADAP SIKAP MENTAL. Pengaruh Pendidikan Kewirausahaan, Motivasi Berwirausaha Dan Lingkungan Keluarga Terhadap Mental Kewirausahaan, 5, 13027.

Yuyus Suryana \& Kartib Bayu. (2010). Kewirausahaan, Pendekatan Karakteristik Wirausaha Sukses. Jakarta: Kencana Prenada Media Group. 